\title{
From Hackensack to the White House: The Triumph and Travail of E. Frederic Morrow
}

\section{Michael J. Birkner}

\section{DOI: http://dx.doi.org/10.14713/njs.v3i2.84}

Four decades after arranging a historic meeting in the White House of President Dwight D. Eisenhower and African-American leaders on June 23, 1958 former Eisenhower assistant Rocco Siciliano recounted the back-story of the meeting, highlighting its inherent drama and significance. In the course of sharing his recollections Siciliano paid tribute to an AfricanAmerican member of the White House staff, E. Frederic Morrow, calling him a "true pioneer in the American black civil rights movement." Added Siciliano: "[Morrow's] impact on civil rights progress has yet to be appreciated." "Judging "impact" by one individual on a large-scale movement is tricky business. But, as this article notes, there should be no doubt that in serving President Eisenhower New Jersey native Fred Morrow advanced the civil rights cause. The fact that his five-and-a-half-year tenure as a black man in the White House was not always happy or consistently productive of the kinds of initiatives on behalf of racial equality that he advocated should not obscure his contributions.

When historians discuss E. Frederic Morrow and civil rights in the Eisenhower White House, most of them focus on his discomfort in an administration in which key figures, including the president, lacked empathy for the indignities daily faced by African Americans and preferred to put the issue of race on a side burner. ${ }^{2}$ Morrow contributed to this interpretation with his

\footnotetext{
${ }^{1}$ Siciliano's unpublished 1998 memoir, "Civil Rights and Black Leaders Meeting with President Eisenhower of June 23, 1958," was prepared for the Papers of Martin Luther King project and kindly shared with this paper's author by Mr. Siciliano.

${ }^{2}$ Kenneth O'Reilly, Bruce Dierenfield, Taylor Branch and other scholars have emphasized the president's lack of interest in black civil rights, taking note of tensions within the White House staff about responding to black America and the segregationist whiplash against Brown v Board of Education. See for example Robert Caro, Master of the Senate: The Years of Lyndon Johnson (New York: Random House, 2002), 777-781, 918-919, 925-927, which focuses mostly on Eisenhower's inability to get a strong civil rights bill through Congress in 1957 because he was outmaneuvered by Lyndon Johnson; Taylor Branch, Parting the Waters: America in the King Years, 1954-63 (New
} 
publication of a heavily edited version of his White House diary, a painfully candid document. In the diary Morrow oscillated between expressions of pride at his status, support for a president whom he believed wanted to do right by black Americans, and frustration as he waged an uphill battle to elicit the president's attention and his engagement on this matter. The strongest impression he left was that the Eisenhower Administration did not have its heart in advancing black civil rights. For various reasons, not least his skin color, Morrow's experience in the White House was less congenial and, in truth, less team-centered than the experience of most other junior staff members. $^{3}$

That Fred Morrow would have risen to the level of an executive assistant to the president of the United States is in itself a remarkable story. Morrow was born in Hackensack, New Jersey, a commuter suburb of New York City, in 1909. The second child and oldest son in a tight-knit

York: Simon and Schuster, 1988), esp. 113, 180-183, 219-222, 233-237, 248-250, 344; Bruce Dierenfield, The Civil Rights Movement (rev. ed., Harlow, England: Pearson Publishing, 2008), 25-31; Kenneth O'Reilly, Nixon's Piano: Presidents and Racial Politics from Washington to Clinton (New York: Free Press, 1995); Robert F. Burk, The Eisenhower Administration and Black Civil Rights (Knoxville: University of Tennessee Press, 1984). Manfred Berg's "The Ticket to Freedom:” The NAACP and the Struggle for Black Political Integration (Gainesville: University Press of Florida, 2005), 191-198; Russell L. Riley, The Presidency and the Politics of Racial Inequality: Nation-Keeping from 1831 to 1965 (New York: Columbia University Press, 1999), esp. chapter 6; and Paula F. Pfeffer, A. Philip Randolph, Pioneer of the Civil Rights Movement (Baton Rouge: Louisiana State University Press, 1990), follow this line in portraying Eisenhower as not merely lacking an interest in the cause of black civil rights but as largely ineffective in advancing minority rights, with the major exception of his response to the crisis in Little Rock. For a different view, highlighting Eisenhower's strong record on civil rights in the areas of federal jurisdiction and his appointments to federal courts, as well as a reminder that Eisenhower introduced and fought for but ultimately could not get, a civil rights measure in 1957, see David Nichols, A Matter of Justice: Eisenhower and the Beginning of the Civil Rights Revolution (New York: Simon and Schuster, 2007). For a fascinating window into Eisenhower's viewpoint on black civil rights shortly after his retirement from the presidency, see Simeon Booker, "What 'Ike' Thinks About Negroes," Ebony 18 (December 1962): 83-86, 88, 89, 92.

${ }^{3}$ Black Man in The White House: A Diary of the Eisenhower Years by the Administrative Officer for Special Projects, The White House, 1955-1961 (New York: Coward-McCann, Inc. 1963). Although Morrow's sympathies with the President are a consistent thread in the diary, his frustrations in trying to move the Eisenhower White House to focus on the indignities and injustices blacks faced every day in the U.S. were equally prominent. As a consequence, scholars inclined to fault Eisenhower for not doing more for the civil rights movement have found Morrow a convenient source to sustain their arguments. My generalizations about Morrow's experience in the White House are drawn from oral histories. These include those Morrow did for the Columbia University Oral History project as well as his interview with film-maker George Colburn for Colburn's Eisenhower archive. I conducted personal interviews with Eisenhower staff members Bradley Patterson, Roemer McPhee, Douglas Price, and Edward McCabe, and further drew on their interviews (and those of Albert Toner and Robert Kieve) for the Eisenhower Oral History Project. 
and aspirational black family, Morrow's Hackensack experience proved the wellsprings of a life in which he felt he never entirely fit comfortably in any of the circles in which he travelled. Fred's father, John Eugene Morrow, was Methodist pastor to small black congregations in Bergen County. He made ends meet through part-time work as a custodian at the public library in Hackensack so his family could have access to books. During Fred Morrow's growing up years his hometown was a thriving community. As county seat and an increasing center of industry and commerce, Hackensack boasted several newspapers and the usual range of civic organizations and social clubs, as well as the largest public library in Bergen County. ${ }^{4}$

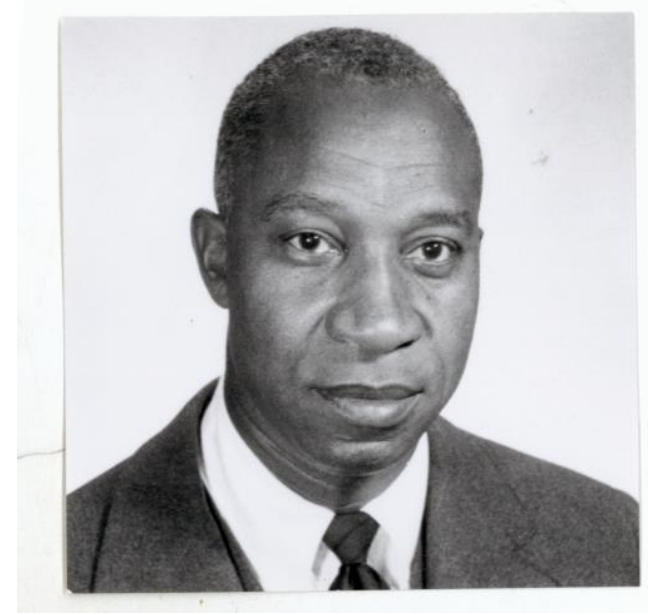

New Jersey native E. Frederic Morrow overcame the limitations of his childhood in Hackensack to become the first African American to hold an executive position at the White House. Courtesy of the Eisenhower Library, used with permission.
In his memoirs Morrow did not exaggerate when describing the challenges of living in a community where blacks were largely relegated to subordinate social and economic status. Blacks in Hackensack were taken for granted as part of the landscape of cooks, janitors, gardeners, chauffeurs and laborers, the latter often finding work in the paper mills in nearby Bogota. The idea that a black person might seek the same professional opportunities as whites would was, with few exceptions, usually dismissed when not openly discouraged. Morrow encountered this disconcerting reality early on when at his

\footnotetext{
${ }^{4}$ For the Hackensack segment of this paper I have drawn heavily on Morrow's first autobiography, Way Down South Up North (Philadelphia: United Church Press, 1973), chapter one, and materials in the local history files of the Bergen County Historical Society maintained at the Johnson Free Public Library in Hackensack. See also George James, "American Dream, Darkly," The Record [1973] copy accessed in E. Frederic Morrow Papers Box 6, Amistad Collection, Tulane University. Hackensack lacks a scholarly community history. For a very brief but useful précis, see Maureen Dillon, "Hackensack," in Maxine N. Lurie and Marc Mappen, eds., Encyclopedia of New Jersey (New Brunswick: Rutgers University Press, 2004).
} 
father's instigation he went to check out books at the local public library. The librarian, who resented Hackensack blacks' use of the facility, treated them "with utter contempt and discourtesy," Morrow later recalled. "Her favorite trick with us was to discourage taking home the legal number of books (three) to read. She suggested that the books were too complex or scientific for our understanding-or they had just been reserved for someone else." That did not stop the Morrow children from borrowing books. When Morrow refers to a distinct "color line" in Hackensack during his growing up years, he was speaking the simple truth. Social segregation was a way of life, with blacks denied opportunities even to use the local YMCA. Culturally speaking, Hackensack blacks were a "starved populace," lacking opportunities for any significant "cultural development or expression."

Educated in a segregated elementary school but permitted to matriculate at the integrated Hackensack High School, Morrow participated in a wide range of student activities, including theatrical productions and the debate club. Always an avid reader and academic achiever, he came to appreciate the consequences of a black person pressing for vocational opportunities in Hackensack when his older sister Nellie, a student at Montclair State Normal School, applied for a position in 1922 as a practice teacher in the local school system. She hoped to become the first African American teacher in any Bergen County white public school. Racially charged opposition to the appointment spearheaded by the Ku Klux Klan inflamed Hackensack for several weeks in 1922. At one point the Klan rallied and burned a cross in front of the Morrow family residence in the carriage house of an estate on the edge of the city, with the Morrows forced to barricade themselves inside while Morrow senior showed his eldest son, then thirteen years old, how to

\footnotetext{
${ }^{5}$ Forty Years a Guinea Pig, 47. For the library episode, see Way Down South Up North, 65. In a 1974 speech in Hackensack, Morrow referred to his "unhappy youth" there and yet acknowledged his sentimental attachment to the community. Typescript in Morrow Papers, Box 1, Amistad Collection, Tulane University.
} 
operate a Smith \& Wesson 38 revolver if it came to that. It was, Fred Morrow recalled in his memoirs, nerve wracking. ${ }^{6}$

Yet the Morrows were not cowed. If anything, slights and threats only reinforced Eugene Morrow's commitment to widening his family's horizons through education. All of the Morrow children-there were five-applied themselves thoroughly to their studies. All attended college. Fred's younger brother John attended Rutgers College and earned a Ph.D. in French at the University of Pennsylvania, while Fred entered the class of 1930 at Bowdoin College and subsequently earned a law degree at Rutgers while on leave from his professional duties at the NAACP. Nellie Morrow ultimately achieved her goal of teaching full-time in Hackensack, becoming the first black teacher in the county in an integrated school setting and earning wide respect for her qualities as a teacher and mentor.

For his part, though Fred had ambitions for a satisfying professional life, he did not see himself as a racial pioneer, much less as a future member of a presidential administration. Having developed his writing and critical thinking skills during his years at Bowdoin, Morrow's first job out of college was as a social worker at the Social Service Federation in Englewood, New Jersey, a bustling commuter suburb near Hackensack. In 1935 he was hired as business manager for Opportunity Magazine, house organ of the National Urban League, where he helped write and edit copy. ${ }^{7}$ Two years later Morrow joined the NAACP staff as Coordinator of Branches, a position

\footnotetext{
${ }^{6}$ Way Down South Up North, chapter 4. The house was purchased from the owner, a prominent Republican committeewoman and socialite named Edna Conklin, owing to timely assistance offered by another Hackensack notable, former state Senator William Johnson. Johnson held the mortgage to the Morrows' home and surrounding property. For more on Nellie Morrow see unpublished biographical manuscript written by Fred Morrow in his papers in the Amistad Collection at Tulane University; also Ray Pellecchia, "City School Renamed After Education Pioneer," Central Bergen Report, Sept. 30, 1981, in same file. In a reminiscence for a newspaper reporter in 1973 Morrow recalled that because the Morrows lived apart from the black "ghetto" along Railroad Street in Hackensack they were viewed as "biggity" [presumably "uppity"]. James, "American Dream, Darkly."

${ }^{7}$ Morrow recounted his vocational experience in an undated memo for Alfred Moeller, copy in Morrow Papers, Box 3, Amistad Collection, Tulane University. See also Herbert Parmet interview with Morrow, Dec. 1, 1968, an unprocessed oral history interview in Butler Library, Columbia University.
} 
he held until 1950, with long leaves of absence for military service and subsequently matriculation at Rutgers Law School. ${ }^{8}$

Shortly after graduating from Bowdoin and moving back home Morrow joined the New Jersey Republican Party. Over time he became vice chair of the Young Republicans, working to register blacks and organize election campaigns. ${ }^{9}$ It was not, he later recalled, an easy situation, because most of the Republican establishment in New Jersey, including his home county, had little interest in recruiting blacks or advancing their interests. In 1937 Morrow met Walter White, executive secretary of the NAACP, who was looking, Morrow later recalled, for someone dynamic to come and "help with the branches."

Morrow's work for the NAACP is largely unknown to scholars, but it is well documented in the organization's archive at the Library of Congress. During his years as field secretary and branch manager for the NAACP Morrow earned a double-edged reputation. For the black public that took an interest in civil rights matters, Morrow was an often eloquent spokesperson and a courageous recruiter and organizer, willing to venture into the deep South and spread the message that a new day was coming for African Americans. ${ }^{11}$ The second element of Morrow's reputation,

\footnotetext{
${ }^{8}$ In a letter to Lorenzo Somerville, August 20, 1941, NAACP Papers, II: A 592, LC, Morrow says he worked for two years in the legal department of Standard Oil in the 1930s. There is no other mention of this affiliation in any of his papers. Morrow's embattled experienced in the military, which saw him rise from private to major, is best accounted for in the Papers of the NAACP, Series II, Box A-593, Library of Congress.

${ }^{9}$ On Morrow's involvement with the New Jersey GOP see Ab Herman [an aide to Republican U.S. Senator Warren Barbour] to Morrow, May 31, 1940, NAACP Papers, II: A592, Library of Congress. There are several friendly letters from Senator Barbour to Morrow, one of them responding to Morrow's request for intervention with the Roosevelt administration in seeking a position; Barbour pointed out that the administration was not likely to take much account of any recommendation he made. According to a note from Phyllis Scott, Affirmative Action Officer of Bergen County, to Evelyn Haller, February 17, 1988, Morrow was the first African American to be accepted as a member of the Young Republicans. In 1932, the letter says, Governor Morgan Larson sent state troopers to escort Morrow to the podium to make a speech. Morrow Papers, Box 1, Amistad Collection, Tulane University. ${ }^{10}$ Parmet interview, Dec. 1, 1968, Columbia University Oral History archive.

${ }^{11}$ For details of Morrow's work while on the road attempting to build morale in the hinterlands and membership for the NAACP, his diaries in the NAACP Papers, Series II: A 592, Library of Congress, are most helpful. See also Morrow 1968 Oral History for the Civil Rights Documentation Project, Amistad Collection, Tulane University. Morrow's difficulties building membership and raising funds in the deep South are discussed in a number of documents, notably his memo to the Executive Staff, April 4, 1940, NAACP Papers, Series II: A 592, LC.
} 
inside the NAACP, was that he was a prima donna whose elevated notion of his worth and sensitivities to slights time and again put him at odds with colleagues. Morrow repeatedly clashed with another rising star in the organization, Roy Wilkins, complaining that he did not get enough credit for his work, was not paid well enough, and was not given better assignments. Ultimately Wilkins, who had the ear of NAACP director Walter White, prevailed in their internal struggle. In 1950 Morrow was asked to leave, albeit given time to find work and hence to depart with a minimum of public embarrassment or acrimony. ${ }^{12}$

It took months for Morrow to find an acceptable position, but eventually he found a haven at CBS in New York City, where he was hired as a member of the Public Relations staff. There he devoted much of his time writing descriptions of CBS programs for the television sections of newspapers and magazines. Morrow recalls contributing to the development of Edward R. Murrow's "See it Now" series on the network, though what his specific contribution was to this program is not known. ${ }^{13}$ While working for CBS Morrow was invited to join the Eisenhower Presidential campaign in 1952. His recruitment came as a result of several GOP leaders-among them New Hampshire Governor Sherman Adams and New Jersey Governor Alfred E. Driscoll-searching for opportunities for the Republican Party to connect with black voters. What better way to send a message that the Eisenhower team cared about African Americans, in light of the Democrats' nomination of an Alabama segregationist to the Vice Presidency, than to appoint

\footnotetext{
${ }^{12}$ NAACP Papers, Series II: A592. Morrow's run-ins with executive director Walter White and White's second in command Wilkins, were frequent and on occasion acidulous. At one point Wilkins described Morrow's various personality quirks and failings, including his penchant for "self-dramatization." On this see Wilkins to Morrow, April 2, 1943, NAACP Papers, Series II: A 593. On Morrow's firing, see his letter to Wilkins, April 1, 1950, Papers of the NAACP, Series II, A 593-A, Library of Congress. In it he called Wilkins' explanation for the dismissal "full of insinuations and half-truths" and later called attention to what he saw as a "bald lie" about his performance on behalf of the NAACP. On one principled disagreement with White, see Patricia Sullivan, Lift Every Voice: The NAACP and the Making of the Civil Rights Movement (New York: The New Press, 2009), 259-263.

${ }^{13}$ Morrow oral history conducted in two sittings for the Eisenhower Project at Columbia University by interviewer Ed Edwin, 1968.
} 
a black man as a staff member who reached out to blacks and reminded them that a new day was possible under the Republicans? Such was Governor Driscoll's logic. Adams, the de facto manager of the campaign train, bought the idea. ${ }^{14}$

Always sensitive to the possibility that he was hired as a token rather than an adviser with a meaningful role to play, Morrow insisted that his responsibilities had to be broadened beyond outreach to black voters. Hence his formal title was as "Adviser and Consultant" to the candidate. ${ }^{15}$ He knew and accepted this core mission and embraced it with gusto, taking special satisfaction in riding in motorcades through cities across the USA in close proximity to the presidential candidate and being noticed by the local media. Morrow delivered many hard-hitting campaign speeches when called on to address African-American audiences, and kept in touch with Republican operatives in major cities. In late October, when Eisenhower and his entourage visited Morrow's home town of Hackensack the candidate made a point of praising him, much to the discomfort of local Republican leaders, as a local boy made good. ${ }^{16}$ Morrow travelled thousands of miles with the campaign both by train and airplane-the latter used most extensively in the South, to avoid the likely possibility that local hotels would refuse the patronage of a black person. ${ }^{17}$

\footnotetext{
${ }^{14}$ Morrow told interviewer Ed Edwin for the Columbia University Oral History Project that he suspected the CBS President Bill Paley had recommended him to the Eisenhower campaign, but there is no documentary evidence to support this statement. In Forty Years a Guinea Pig, 73-74, Morrow credits Republican operative Val Washington with his appointment to the Eisenhower campaign. Washington may well have suggested Morrow's name, but the assignment would not have been made without Alfred Driscoll's and Sherman Adams's endorsement. The Alabama segregationist running on Adlai Stevenson's ticket in 1952 was U.S. Senator John Sparkman.

${ }^{15}$ Diary entry, Feb. 8, 1954, Morrow Papers, Box 1, DDEL; also Morrow oral history interview with Ed Edwin, Columbia University Oral History project, 1968.

${ }^{16}$ For details of the controversy engendered by Eisenhower's positive references to Morrow, see his original (unpublished) diary entry for February 8, 1954, Morrow Papers, Box 1 DDEL. Several Bergen County Republican leaders privately told Eisenhower he had no business praising Morrow, who they saw as no friend of theirs and no team player in Bergen County GOP affairs; Eisenhower brushed off their complaints, but later told Morrow about them. In what was to prove something of bad trend for Morrow, he was unable to be present in Hackensack when Eisenhower praised him to a huge crowd at the Court House. He was putting out some political fire in St. Louis at the time, but the remarks were published in the local papers, including the Bergen Evening Record, whose editor shared the story with him.

${ }^{17}$ Michael J. Birkner, "Electing Ike: Sherman Adams and the Making of the President, 1952," draft book manuscript, discusses this issue.
} 
On the campaign trail Morrow reached out to black voters in the venues where Eisenhower spoke. He wrote memos to Sherman Adams and to other aides close to the candidate, urging certain initiatives to catch blacks' attention and win their support, perhaps the most important of them being memos urging Eisenhower to promise to support creation of a Fair Employment Practices Commission. Such an initiative made Eisenhower uncomfortable; the most he would do was encourage states to act. Morrow's advocacy demonstrated one of his central traits-a willingness to stick his neck out for causes in which he believed. ${ }^{18}$

As the campaign unfolded Morrow seems to have become more comfortable, in part because Sherman Adams's wife Rachel made a point of including him in pranks and social activities, and special events, including the celebration of Ike's birthday on October 14, when the candidate was off duty. Sherman Adams for his part would often test Morrow's abilities by tossing press accounts of Democratic attacks on Eisenhower on to his lap and asking him what he'd say in response. It was daunting but at the same time exhilarating work. During a rare opportunity to spend time one-on-one with the candidate, Morrow had the moxie to tell Eisenhower that a speech he had delivered in Iowa was not very good. Morrow recalled that he told Eisenhower he needed to use language that better connected with average people. Eisenhower responded, "By golly, you may be right." 19 The general clearly made enough connections to win a landslide victory in November 1952 over his Democratic opponent, and carried in a Republican Congress with him.

\footnotetext{
${ }^{18}$ Herbert A. Parmet, Eisenhower and the American Crusades (New York: The Macmillan Company, 1972), 438439 and Stephen A. Ambrose, Eisenhower: Soldier, General of the Army, President-Elect, 1890-1952 (New York: Simon and Schuster, 1983), 567. For Eisenhower's discomfort with the issue, Louis Galambos and Daun Van Ee, eds., The Papers of Dwight D. Eisenhower, vol. 13: NATO and the Campaign of 1952 (Baltimore: The Johns Hopkins University Press, 1989): 1298, 1382. For the NAACP's frustrations moving legislation forward on fair employment practices, Denton L. Watson et al., eds, The Papers of Clarence Mitchell Jr., IV: 1950-1954 (Athens, OH: Ohio University Press, 2010), "Introduction," ccv-ccxcvi. On Morrow efforts relating to the FEPC, Morrow interview with Herbert Parmet, 1968, Columbia University Oral History Archive (unprocessed collection).

${ }^{19}$ Morrow interviewed by Ed Edwin for the Eisenhower Oral History Project. For a more detailed (and variant) account of this episode, with Eisenhower responding "maybe we'll have to do something to get the message across," see Forty Years a Guinea Pig, 75-77, quote on 77. For accounts of Rachel Adams's efforts to include Morrow in
} 
As a result of his work on Eisenhower's successful campaign, and the connections he made with Eisenhower's right hand man, Morrow anticipated an appointment on the White House staff when the new administration took office. Sherman Adams apparently promised this to him, at least in Morrow's recollection. Consequently, Morrow resigned his position at CBS and waited for the phone to ring. But the phone call never came, not even once the new administration took office in January 1953. With his "bank account running low," as he later recalled, Morrow made repeated calls to the White House, seeking an explanation or update, but he had no success reaching Adams, newly installed as Eisenhower's Chief of Staff. Maxwell Rabb, who served as Cabinet Secretary, did not return his calls either, until finally he told Morrow straight out that there would be no position for him in the White House and to stop pestering him. ${ }^{20}$

As best the situation can be sorted out, Morrow was the victim of internal staff politics. Early in the Eisenhower presidency Adams had not yet established himself as primus inter pares on the staff. Another key figure, Congressional liaison director Wilton Persons, an Alabama native, had made it clear that "he would lead the staff out of the White House the day I showed up.” Eisenhower wanted Persons on his team, and Adams was in no position to disregard Persons' threat, because it may well not have been a bluff. Consequently, Morrow's immediate hopes for a White House position were dashed. ${ }^{21}$ Embarrassed by this circumstance, Adams tried another

social events that demonstrate her solidarity with him, see Morrow's unpublished memo titled "Rachel Adams" in Papers of E. Frederic Morrow, Box 1, Dwight D. Eisenhower Presidential Library. Morrow's recollections of being accorded increasing responsibilities by Adams on the train are in a handwritten addendum to his draft recollection of the 1952 campaign in E. Frederic Morrow Papers, Box 4, Amistad Collection, Tulane University.

${ }^{20}$ Ibid., 86-89.

${ }^{21}$ Morrow interview for the Civil Rights Documentation Project, Amistad Collection, Tulane University, accessed in Morrow Papers at Tulane, Box 3; Morrow interview with Thomas Soapes, 1977, Eisenhower Library Oral History Project. In the interview with Soapes Morrow suggests that Max Rabb did not want any competition in the realm of minority affairs in the White House and consequently was unsympathetic to Morrow on the matter of his appointment in 1953. That Adams was trying to follow through on his promise to Morrow may be inferred from his request to J. Edgar Hoover for a confidential FBI report on Morrow, February 11, 1953, Confidential File, Name Series, Box 3, DDEL. 
tack. In Spring 1953 he called on his friend Sinclair Weeks of Massachusetts, the Secretary of Commerce, and with Weeks' assent assigned Morrow a position as a business affairs adviser to the department. It was not a White House posting, but it was close enough, providing Morrow both with the paycheck he desperately needed and a consolation prize that got him to Washington DC for service to the new administration. ${ }^{22}$

Although Morrow's name shows up not at all in Weeks's diaries for 1953-1955, he recalled his relationship with the Secretary and his chief assistants as cordial and his work-mostly summarizing press coverage of the economy and writing reports on ways the federal government could assist small businesses-as satisfying. Morrow did not enjoy a social life in Washington, even within the African-American community. He found the "loner" approach in a segregated city the best way to go. For relaxation he took a train home to Hackensack most weekends to see family and friends and play golf. ${ }^{23}$

Much as he said he enjoyed his work at Commerce, Morrow would be fully satisfied with nothing less than a White House appointment, and he was not shy reminding Sherman Adams of the original promise made in wake of the 1952 presidential campaign. By the summer of 1955 , with Sherman Adams having emerged as a primary influence in running the Eisenhower White House, Adams was in a position finally to accomplish that end. On July 11, 1955 Morrow was appointed to the Special Projects staff of the Executive Office and given a portfolio that, directly, had little to do with civil rights. ${ }^{24}$

\footnotetext{
${ }^{22}$ Several sources credit RNC "Negro adviser" Val Washington with lobbying Weeks on Morrow's behalf. That is certainly possible, but a few words from Sherman Adams doubtless carried more weight with the Secretary.

${ }^{23}$ Forty Years a Guinea Pig, 98, 136, 147 and Morrow unpublished diary, DDEL. Weeks Diary is in Box 82 of his papers at Dartmouth College's special collections library.

${ }^{24}$ Doubtless Morrow's appointment was also encouraged by rising African American activism on the civil rights front in the wake of the Brown decision. When asked about this in 1968 by historian Herbert Parmet, Morrow agreed that "it wasn't entirely coincidental" that he was appointed to the White House staff in 1955. For Adams's memo
} 


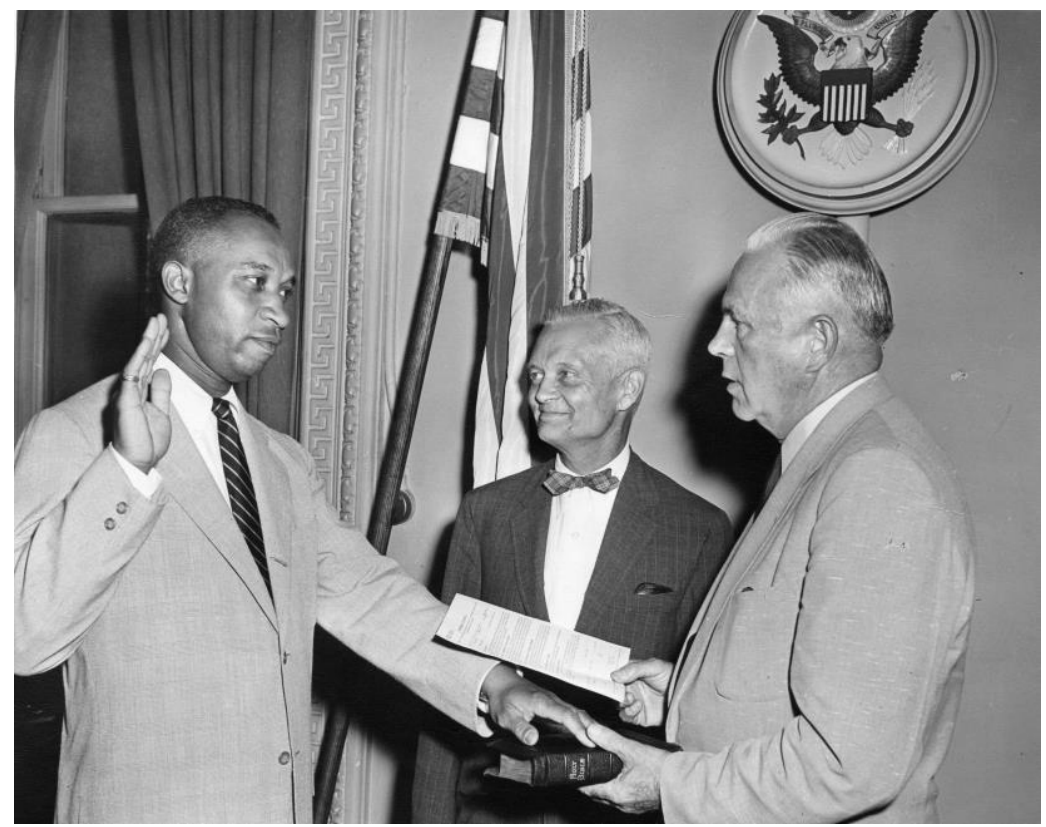
Morrow takes the oath of office in 1955. The fellow standing in the middle is Sherman Adams, Ike's Chief of Staff. The man administering the oath is unidentified. Courtesy of the Eisenhower Library, used with permission.

Morrow's service in the Eisenhower Administration was both the greatest moment in his long life and a cross he had to bear. Some senior members of the White House staff, including Sherman Adams, Special Counsel Gerald Morgan, Economics Adviser Gabriel Hauge, National Security Adviser Robert Cutler, and Press Secretary James Hagerty, were welcoming and supportive of an African American associate. ${ }^{25}$ Most of the junior members treated Morrow as he would want to be treated, though they were so absorbed in their own White House duties and family obligations that they had little opportunity to develop a social friendship with him. ${ }^{26}$ There was also a distinct discomfort in some quarters, notably evidenced in the correct but distinctly cool relations with Wilton Persons, awkward encounters with various unnamed staff members at social gatherings, such as Christmas parties and a picnic at Gettysburg, and the unwillingness of several white secretaries to work for Morrow. When Morrow told Sherman Adams that he could not find any suitable place to eat outside the White House, Adams arranged to admit him to the White

appointing Morrow, see Morrow Papers, Box 3, Amistad Collection, Tulane University Special Collections. For Morrow's account of his swearing in, a red-letter day in his life, Forty Years a Guinea Pig, 94-96.

${ }^{25}$ Morrow names them in Black Man in the White House, 17.

${ }^{26}$ I draw my conclusion about this from interviews I have conducted with a number of Eisenhower staff members, including Douglas Price, Bradley Patterson, Edward McCabe, Roemer McPhee, and William B. Ewald. 
House mess and accompanied him to lunch for a "full week so others would understand, from the top," that Morrow was part of the team. ${ }^{27}$

In his oral histories and memoirs Morrow referred with satisfaction to his status as a member of the "mess" and with pleasure to various social outings with White House staff members and the president. On the rare occasions when a White House staffer extended a social invitation, such as when the Gerald Morgans invited Morrow and his wife to brunch or Rachel Adams' efforts to include Catherine Morrow in White House wives' activities, Morrow was touched and he would never forget. Yet there was another, less inspiriting, side to the story. Throughout the Eisenhower presidency Morrow continued his practice of retreating to North Jersey for recreation and relaxation on weekends and of self-segregating rather than deal with social isolation or potentially unpleasant encounters. In the White House Morrow had to step gingerly, particularly with such senior staff members as Persons and Max Rabb. ${ }^{28}$

Morrow's self-imposed social isolation from Washington's black community was a longstanding defense mechanism. In his affecting memoir of growing up in Hackensack, Morrow recalled his lack of affinity for the majority of his black peers, who viewed him as foolish or "uppity" for modeling "white" ways in dress and demeanor and his focus on his studies. Hackensack whites, for their part, would not accept Morrow as a social equal; as already noted, neither did some members of the Eisenhower administration. Consequently, Morrow would for

\footnotetext{
${ }^{27}$ On the coldness that some staffers exhibited towards him, see diary entry of July 12, 1955, Black Man in the White House, 17. "Old man Jim Crow had followed me right into the White House," Morrow observed in Forty Years a Guinea Pig, 98. In that recollection Morrow emphasizes his refusal to be accorded an African American secretary when none were currently in the White House secretarial pool. For admission to the White House mess, Simeon Booker, "Black Man in the White House," Ebony (April 1961): 79. This same article includes a photo of a picnic for Eisenhower staffers at the Gettysburg Farm, and the depiction of Morrow talking with his wife while the staffer immediately adjacent to him was leaning in a different direction, is suggestive of the dynamic Morrow had to deal with in Eisenhower's White House.

${ }^{28}$ On his self-imposed "hermitlike life" and decision to spend weekends in North Jersey and New York City, see Black Man in the White House, 42-43. See also Booker, "Black Man in the White House," 79.
} 
most of his life live as an outside man, a status on which he often brooded but which he felt powerless to break through. Ultimately Morrow was willing to pay the price of social isolation because he wanted to make a difference in the world. Working in the Eisenhower White House was a means to that end.

As he had done in accepting a position on the Eisenhower campaign train, Morrow felt obliged to make it clear to both Eisenhower and Sherman Adams that he did not want to be singled out as a token, or even as the administration's "race man." "I told the president," he later recalled," [that] it was anathema to me to be an expert on myself." 29

Morrow's precise title in the White House was Administrative Officer for the Special Projects Group. His major duty was to oversee the setting up and provisioning of special White House Commissions on matters relating to economics, science, technology, and other matters as they arose, such as Hungarian Relief in 1957. Overseeing a small professional staff, Morrow kept tabs on payrolls, job titles, and perquisites for members of the White House staff and their aides. His responsibilities ranged widely, from allotting parking spaces to members of special commissions to security and disposal of "waste" documents. Positioned in a handsome, highceilinged office that once had been used by President William McKinley, Morrow felt good about what he represented to the black community nationally and what he was trying to accomplish as part of the Eisenhower administration. ${ }^{30}$

By 1955, civil rights was emerging as a front-burner challenge for an administration that was committed to equal rights on the legal field. In this realm, as historian David Nichols has

\footnotetext{
${ }^{29}$ Civil Rights Documentation Project oral history with Morrow, 1968, Morrow Papers, Box 3, Amistad Collection, Tulane University.

${ }^{30}$ On Morrow's responsibilities in the White House as special projects manager, see documents in his papers at DDEL, Box 1. In this box a researcher will find numerous memos to Morrow from fellow staffer Douglas Price, whose duties overlapped in significant respects with Morrow's on administrative and security matters in the Executive Office Building. Price never had responsibilities in the area of civil rights.
} 
shown, Eisenhower worked in close concert with his Attorney General, Herbert Brownell to assure that all Americans were treated equally in federal jurisdictions, as a "matter of justice." Nonetheless, with exceptions among senior staff, the Eisenhower Administration was less than emotionally committed to the struggle for equality. Neither Eisenhower nor the great majority of white America considered racial equality as a moral imperative. In the South segregation, embedded in a culture of white supremacy, was considered an immutable fact of life. ${ }^{31}$

During the first Eisenhower Administration (1953-1957) Max Rabb, a former aide to Henry Cabot Lodge during Lodge's years in the U.S. Senate, served both as cabinet secretary and adviser on minority issues. Although Morrow had been stiff-armed by Rabb in 1953 as he tried to pursue the promise Sherman Adams had made about a White House appointment, the two men worked reasonably well together. In the latter years of Rabb's White House tenure, they developed something of a rapport. ${ }^{32}$ That said, Morrow's efforts to reach the president with counsel on civil rights issues were generally thwarted by Rabb, who believed that the president should not be burdened on this subject. Rabb never shared Morrow's recommendations with the president, as Morrow recalled and presidential special assistant Rocco Siciliano would later confirm. ${ }^{33}$ In an ideal world, Morrow believed, there would be no need for a minority adviser, since the system

\footnotetext{
${ }^{31}$ Nichols, A Matter of Justice, passim; Herbert Brownell, Advising Ike: The Memoirs of Attorney General Herbert Brownell (Lawrence, KS: University Press of Kansas, 1993), chapters 11, 12.

${ }^{32}$ It is evident that Rabb often blocked Morrow's memos from reaching Sherman Adams or the president, and sometimes proved short-tempered with Morrow's advocacy for minority rights. Yet in his memoir Morrow insisted that Rabb was an ally and a good friend to black Americans. He was genuinely sorry when Rabb resigned in April 1958 even though Rabb's resignation would result in shifting Rabb's civil rights portfolio to Morrow. See on this Black Man in the White House, 216 and Forty Years a Guinea Pig, 160-162. Rabb, Morrow concluded, was "perhaps the only person on the White House staff who showed deep personal concern about the plight of minorities in the country." (Quote on page 162.) For a good brief discussion of Rabb's duties as a "troubleshooter" for the administration, see Herbert Brownell, Advising Ike: The Memoirs of Attorney General Herbert Brownell (Lawrence, KS: University Press of Kansas, 1993), 186.

${ }^{33}$ Siciliano was specifically referring to the matter of a White House meeting with black leaders. Walking on Sand, 157.
} 
would "just treat all Americans in the same manner." But that was not the situation in the United States in the 1950s, and Morrow found himself "inevitably" drawn into minority affairs.

Over time Rabb passed on to Morrow the increasingly voluminous correspondence from African Americans on racial issues, starting with demands that the administration take a more proactive role in prosecuting the murderers of Chicago teenager Emmett Till, who had been kidnapped, savagely beaten, and then shot to death while visiting relatives in Mississippi in 1955. However, when Morrow suggested in wake of the Till case that President Eisenhower convene a conference of clergy, white and black, to discuss the moral implications of the case, Rabb gave him "a tongue lashing" on "the Negro's attitude toward securing his civil rights," which Rabb said was "too aggressive" and too "ungrateful" to the administration for all it had already done for African Americans. Rabb said he was speaking not just for himself but for "most" of the "responsible officials" in the White House who were "completely disgusted" with the black community. ${ }^{34}$ All Morrow could do was back off.

Shortly thereafter, the attempt by a young African-American woman, Autherine Lucy, to matriculate at the University of Alabama provoked a major firestorm. Once again Morrow weighed in on what he hoped the administration would do. In neither the Till case nor Lucy's bid to integrate the university did the president make strong public statements, though he did order the FBI to pursue Till's murderers, who were ultimately arrested, tried, and quickly acquitted by a jury of their peers. ${ }^{35}$

\footnotetext{
${ }^{34}$ Black Man in the White House, 46-48.

${ }^{35}$ For varying takes on the Administration and the Lucy case see Morrow, Black Man in the White House, 49-51, Branch, Parting the Waters, 167-168, 181; Parmet, Eisenhower and the American Crusades, 442; Nichols, A Matter of Justice, 124-125, 127; and E. Culpepper Clark, The Schoolhouse Door: Segregation's Last Stand at the University of Alabama (New York: Oxford University Press, 1993). Asked about the issue at a press conference on February 8, 1956, Eisenhower said he hoped to avoid "any interference" as long as Alabama did what it could to "straighten [the situation] out." Public Papers of the Presidents: Eisenhower, 1956 (Washington, D.C.: U.S. Government Printing Office, 1956), 233-234.
} 
During these episodes, the playing out of the Montgomery Bus Boycott, and the rise of massive resistance to school integration, Morrow was deeply invested, suggesting responses to citizen input and shaping the administration's message to the black community. Recognizing Morrow's abilities as a public speaker, Sherman Adams sent him on the road as the administration's representative at meetings of civil rights organizations nationwide. Ultimately Morrow made what he reckoned as 300 speeches on behalf of the administration, highlighting the accomplishments of the administration while acknowledging that there were still miles to travel before full racial equality would be achieved in the USA. On several occasions Morrow raised eyebrows, or provoked serious criticism from within the black community, as for example when he delivered a speech in Atlantic City before a Black Elks national meeting by criticizing blacks who spent their money on whiskey, cosmetics, cars, and furs rather than focusing on gaining an education and building businesses. Morrow responded to criticism of his remarks by claiming his critics took them out of context. He was gratified when Roy Wilkins of the NAACP defended $\operatorname{him}^{36}$

When not travelling or occupied with correspondence, Morrow worked on two tracks on civil rights matters. On one of them he wrote many memos to senior staff and the president. As Morrow later recalled, "I tried to formulate a plan of whenever anything was vital, of putting it in a memorandum form and then probably getting it to [Eisenhower's] personal secretary [Ann Whitman] or someone who would see him many hours during the day to make sure it got to him.",37

\footnotetext{
${ }^{36}$ On this see "Eisenhower's Negro Aid[e] Chides Race on Luxuries," New York Herald Tribune, August 23, 1955; Leo Bohanon to Morrow, August 24, 1955; Morrow to Roy Wilkins, August 30, Sept. 6, 1955; Morrow to Cora Patton, August 31, 1955; Leo Bohanon to Roy Wilkins, August 24, 1955; Roy Wilkins to Leo Bohanon, September 2, 1955; Leo Bohanon to Roy Wilkins, September 30, 1955; Roy Wilkins to Leo Bohanon, October 13, 1955, all in Morrow folder of NAACP Papers, 1940-1955, Series II, Box 425, Library of Congress.

${ }^{37}$ Interview with Morrow, Civil Rights Documentation Project oral history project, Amistad Collection, Tulane University. Morrow often said in interviews that the President was surrounded by "southern" advisers who did not want him getting involved in civil rights, so it was always an uphill effort, but one he felt he needed to make.
} 
Beyond this, however, Morrow was increasingly seen as the go-to person for black leaders who sought to influence the White House on one issue or another, especially so once Max Rabb departed the White House in spring 1958. Having succeeded Walter White as national director of the NAACP, Roy Wilkins put old grievances with Morrow aside for the cause they both wanted to advance. Morrow responded in kind. ${ }^{38}$

Other black leaders, among them Lester Granger of the National Urban League, and a rising star in the civil rights firmament, Martin Luther King, Jr., were frequently in touch with Morrow, in some instances seeking a meeting of black leaders with the president. When President Eisenhower introduced his civil rights bill in 1956, and subsequently reintroduced it in 1957 , Morrow counseled black leaders about strategies, emphasizing that it wasn't the president they had to persuade but members of Congress. Ultimately the enforcement provisions in the 1957 bill were gutted, owing in good measure to Texas Senator Lyndon Johnson's maneuvers. Eisenhower had to decide whether to sign a flawed bill or get nothing at all. Baseball great Jackie Robinson, among others, wrote Morrow demanding the president refuse to accept the bill, a view Morrow shared and expressed to his colleagues on the White House staff. Ultimately Eisenhower concluded that half a loaf was better than nothing, and he signed the first significant civil rights measure to pass Congress since Reconstruction. ${ }^{39}$

\footnotetext{
${ }^{38}$ Despite his rapprochement with Morrow Wilkins frequently made waspish comments or frontal assaults on the Eisenhower Administration for what he felt were its failings in the realm of civil rights. This naturally complicated Morrow's efforts to bring the president into closer contact with NAACP leaders and other civil rights activists. The administration tended to see the activists as pushy and "radical" whereas the activists perceived themselves as simply seeking justice for black Americans that was long overdue.

${ }^{39}$ There are many accounts of the passage of the 1957 Civil Rights bill, none of them more exhaustive than Robert Caro's in Master of the Senate, 850-1004. Caro portrays the measure that Eisenhower signed as Lyndon Johnson's triumph. For an incisive account, looking at the legislation from the president's viewpoint, see Nichols, A Matter of Justice, chapter 7. For the determined efforts of segregationists in the Senate to block Eisenhower's bill, see Keith I. Finley, Delaying the Dream: Southern Senators and the Fight Against Civil Rights (Baton Rouge: Louisiana State University Press, 2008), chapter 4. Jim Newton, Eisenhower: The White House Years (New York: Doubleday, 2011), 242-246, offers a brief but judicious analysis. For Morrow's memo warning against softening the Civil Rights bill, see Morrow to Adams, July 12, 1957, Morrow Papers, Box 9, DDEL. Jackie Robinson's telegram to
} 
The maneuvering to enact, defeat, or amend Eisenhower's Civil Rights bill in 1957 was one of the two great stories that year in the ongoing campaign for black civil rights. The other was the confrontation at Little Rock where Arkansas Governor Orval Faubus, appealing to a segregationist white electorate, refused to cooperate with court ordered integration of Central High School. Given Morrow's increased engagement with such matters, it would be logical to expect him to have been in the thick of the action in the weeks before Eisenhower ordered federal troops to Little Rock and made a nationally televised address explaining why it was necessary. ${ }^{40}$ Such was not the case because of an accident of timing. Morrow had just been married to a Chicago social worker, Catherine Boswell, whom he had met at a conference there in 1956. The Morrows spent most of September and early October on their honeymoon in Hawaii. ${ }^{41}$ Morrow was thus thousands of miles from the main stage in one of the great civil rights set pieces of the Eisenhower presidency.

In the wake of Little Rock Morrow naturally gravitated to the issue of school integration elsewhere, collaborating with senior staff, including Sherman Adams, as the administration's options were assessed and its priorities formulated. Ultimately the administration made its presence felt primarily in asserting the importance of enforcing court orders and in the president's judicial appointments, notably in the South. As David Nichols has demonstrated, appointing southern judges who would enforce Brown was intentional, consistent, and efficacious. ${ }^{42}$ Morrow

\footnotetext{
Morrow opposing the watered down version of the bill that President Eisenhower subsequently signed, dated August 13, 1957, in in White House Central Files, OF-142-A-5, DDEL.

${ }^{40}$ On Little Rock, compressed but helpful discussions can be found in Branch, Parting the Waters, 222-224; Stephen E. Ambrose, Eisenhower the President (New York: Simon and Schuster, 1984), 414-423; Newton, Eisenhower, 247-253; and most satisfying, Nichols, A Matter of Justice, chapters 8 and 9.

${ }^{41}$ Morrow, Black Man in the White House, 173, alludes in an October 7, 1957 entry to a "three-week honeymoon." Forty Years a Guinea Pig jumps over this tempestuous three-week period in regard to Little Rock.

${ }^{42}$ Nichols, A Matter of Justice, 55-58, 75-97, 265-267 and passim.
} 
frequently found himself in an awkward situation in dealings with black leaders who felt this was not enough, and who wanted more action, more quickly, on the civil rights front. ${ }^{43}$

From the early days of Eisenhower's presidency black leaders had been seeking face time with him on a range of issues. ${ }^{44}$ Morrow believed they had a good case to make. He was convinced that a meeting with "responsible" black leaders would send a signal about the administration's seriousness about minority rights, and he was convinced it would pay off politically as well. Morrow was acutely aware of the way segregationist Democrats, primarily from the South and border states, were fighting tenaciously to sustain their system of white supremacy against federal intervention. Putting the president on the side of the civil rights cause was the goal. A meeting where Eisenhower could hear directly the concerns of black leaders was a means to that end. ${ }^{45}$ As previously noted Morrow's memos had to pass through Eisenhower's designated aide for minority affairs, Max Rabb, but Rabb declined to forward them to the president on the grounds that the president had more important concerns. Rabb assured black leaders that their message was "getting through" to the president. In fact, their message was not getting through. Morrow's was a "lonely voice" in the White House, Rocco Siciliano has observed. ${ }^{46}$

\footnotetext{
${ }^{43}$ In his memoir, Forty Years a Guinea Pig, 143, Morrow says that the many letters and phone calls from "irate friends and citizens who were fed up with" Eisenhower for failing to exert moral leadership on civil rights made him begin to "hate" to go to work in the morning. Morrow recalls that he "felt self-conscious and foolish in my speeches throughout the country trying to defend the administration's record on civil rights."

${ }^{44}$ Eisenhower had met with leaders of the NAACP several times prior to the 1958 meeting discussed in this article, including a post-election discussion of civil rights policy in November 1952 and a brief meeting in 1954 on housing policy. See Denton L. Watson et al., eds., The Papers of Clarence Mitchell, Jr., Volume IV, 1951-1954 (Athens: Ohio University Press, 2010), 335, 409.

${ }^{45}$ See, for example, Morrow's memo to Maxwell Rabb, Nov. 29, 1955, as excerpted in Walking on Sand, 166.

${ }^{46}$ Quotes from ibid., 157, 170. For context on Morrow's struggles to avoid being seen as an "Uncle Tom" who was simply window dressing for an administration that allegedly did not care about minority rights, see Parmet, Eisenhower and the American Crusades, 508-509, 525. Leading White House staffers, by contrast, viewed him as "too aggressive." "Every time you come around, you're asking help on a racial matter," one told him. Booker, Black Man in the White House, 84, 86.
} 
Matters took on a different complexion in wake of Rabb's resignation effective May 1958. Weeks later Sherman Adams, the president's Chief of Staff, called Siciliano into his office to ask him to review requests he had been receiving from "diverse" black leaders who wanted a presidential meeting. Siciliano's main responsibility was in the field of personnel management-a large portfolio entailing maximizing fairness and efficiency within the realm of the federal bureaucracy, but he agreed to take on this assignment. Within days he realized that it would "eclipse" all his other work. ${ }^{47}$

Early on in the process of arranging a meeting, Adams and Siciliano addressed the question of how many black leaders should meet the president, and which ones. They soon agreed that the number should be kept low, and that Siciliano would work on specifics. In his memoirs, Siciliano recalled that Adams never consulted with the president before handing him the assignment, though of course there is no way to know for sure that this was the case. Siciliano, who knew Fred Morrow casually as director of the Office of Special Projects, made a beeline to Morrow's office, for good reason. Not only was Morrow the informal liaison of African-Americans with the administration, once Rabb had departed the White House, Adams had assigned him the responsibility of handling White House correspondence involving civil rights and African American concerns. Siciliano's portfolio on civil rights was focused simply on brokering a meeting with black leaders. ${ }^{48}$

Over the next days Siciliano contacted various individuals, starting with Reverend King, who accepted an invitation to meet with Siciliano and Morrow in the White House on June 9. Two of King's suggestions for invitees to the meeting-labor leader A. Philip Randolph and NAACP executive secretary Roy Wilkins-were accepted. Another black leader who was by then well

\footnotetext{
${ }^{47}$ Siciliano, Walking on Sand, 156-157.

${ }^{48}$ Ibid., 158-159.
} 
known to the administration, Adam Clayton Powell, was rejected by Morrow and Siciliano, in part because Powell was then under indictment, but also because neither man trusted Powell would not try to hijack the meeting to serve his own purposes. King accepted their reasoning. ${ }^{49}$ A meeting was scheduled for June 23, 1958 and the president was briefed. In the days beforehand, the executive secretary of the National Urban League, Lester Granger, was added to the list of participants. Once word spread that the meeting would occur, Morrow dealt with the deluge of mail and phone calls from African Americans who wanted to be part of the delegation. It took a toll. Someone leaked his home phone number and there was no rest to be had at home or work; he chose to return to his new Teaneck, New Jersey home for several days to regain his composure, arriving back in Washington for the climactic meeting. ${ }^{50}$

On June 23 Morrow, Attorney General William P. Rogers and Siciliano met early in the day and then briefed the president, counseling him to avoid words like "patience" and "tolerance" which Siciliano pointed out might cause a negative response. (Morrow was prudent enough to know this message would not go down well if he was the messenger; it is evident he coached Siciliano on this delicate matter.) Eisenhower growled, "Well, Siciliano, you think I'm going to avoid good English words?" "No, sir," Siciliano responded. "I was just trying to point out that there are certain things that might cause the wrong reaction." ${ }^{51}$ Siciliano was referring in part to the negative reaction of blacks to Eisenhower's call for "patience" when he spoke to a convention of black leaders in Washington the month before the White House meeting. The meeting had been

\footnotetext{
${ }^{49}$ Ibid., 160-161. For King's perspective on the meeting, see Branch, Parting the Waters, 233-237. Siciliano offers his response to Branch in Walking on Sand, 167-168.

${ }^{50}$ Morrow, Black Man in the White House, 165; idem., Forty Years a Guinea Pig, 166-168; Siciliano, Walking on Sand, 158-161.

${ }^{51}$ Branch, Parting the Waters, 234-235; Siciliano, Walking on Sand, 162.
} 
convened by the National Newspaper Publishers Association, an African American consortium. ${ }^{52}$

However grudgingly, the President accepted this counsel; there is no evidence he used either word in the 50-minute meeting that ensued.

The meeting between the president and black leaders proved a high point of his administration's outreach to African Americans. Siciliano recalled a "passionate" but civil conversation in which the black leaders each had the opportunity to say their piece. Dignified as a Biblical prophet and avoiding any hint of emotion, Randolph opened the discussion with a ninepoint plan for increased White House activism in civil rights. King, Taylor Branch has observed, preached a "short sermon on the powers of moral leadership." His role "was to try to lure Eisenhower into greater activity by summoning up feelings of duty and glory.” Wilkins offered three legislative recommendations, and then came a flash point. Granger reminded Eisenhower that bitterness among African Americans was substantial-perhaps more so than at any other point in his life time. ${ }^{53}$

\footnotetext{
${ }^{52}$ For details on Eisenhower's speech and blacks leaders' negative reaction, see Felix Belair, Jr., "Eisenhower Bids Negroes Be Patient About Rights," New York Times, May 13, 1958; Anthony Lewis, "Negroes Criticize 'Patience' Advice," New York Times, May 14, 1958; and Emma Harrison, “Another Negro Dissents," New York Times, May 14, 1958; also, draft of Charles Roberts's "Periscope" comments for Newsweek, May 17, 1958, copy accessed in Roberts' Papers, Eisenhower Administration Alpha File, Box 3, Herbert Hoover Presidential Library; and Booker, "Black Man in the White House," 82.

${ }^{53}$ Branch, Parting the Waters, 235. For a tart discussion of King's view of Eisenhower's failings as a moral leader, see Stephen B. Oates, Let the Trumpet Sound: The Life of Martin Luther King, Jr. (New York: New American Library, 1982), 129-130. King, Oates avers, was “disgusted with Eisenhower," before and after the June 23 meeting. (Quote p. 130.) See also in this connection King, Why We Can't Wait (New York: Harper \& Brothers, 1964), 143 and David Garrow, Bearing the Cross: Martin Luther King, Jr. and the Southern Christian Leadership Conference (New York: William Morrow and Company, Inc., 1986), 118-119. The nine-point action plan can be accessed in Clayborne Carson et al., eds., The Papers of Martin Luther King, Jr. IV: Symbol of the Movement, January 1957December 1958 (Berkeley: University of California Press, 2000): 426-429.
} 


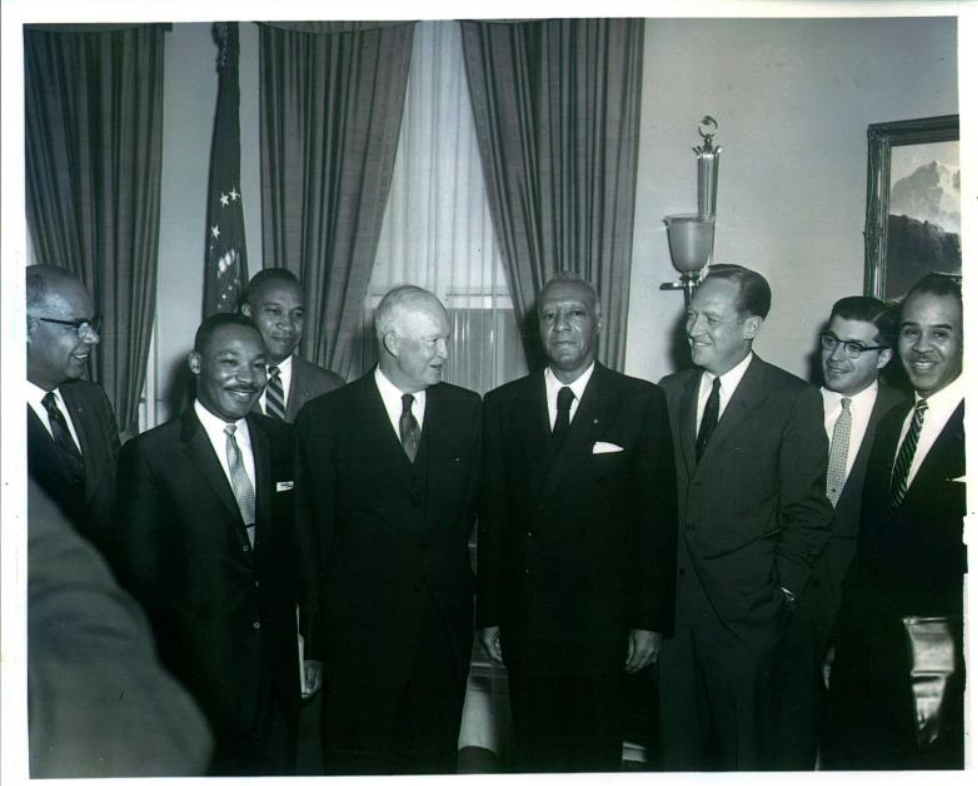

The June 23, 1958 meeting between President Eisenhower and black civil rights leaders, which Morrow helped organize, was one of the high points of his service in the White House.

Left to right in the photo: Lester Granger of the National Urban League; Rev. Dr. Martin Luther King Jr.; Morrow; President Eisenhower; A. Philip Randolph, international president of the Brotherhood of Sleeping Car Porters; William Rogers, Attorney General; Rocco C. Siciliano, Special Assistant to the President; and Roy Wilkins, NAACP president. Courtesy of the Eisenhower Library, used with permission.
Attorney General Rogers, who had participated in the White House planning for the session, had been reading the leaders' nine-point plan as they spoke. Increasingly agitated by some of the language in it, Rogers complained that it was not congruent with the oral testimony of the participants. He emphasized that his office was engaged in "aggressive court action" where the legal facts allowed. He said he wished that the minority community would be more appreciative of all the administration

had done in the previous five years. Perhaps unwisely, he also noted that Roy Wilkins had been willing to abandon the controversial section III of the 1957 Civil Rights Bill introduced by the administration when it became clear there would be no bill passed otherwise. ${ }^{54}$

Granger's comment also elicited a flash of anger from the president, who followed Rogers' comments by expressing his own frustrations with the minority community's lack of appreciation for what he had done on its behalf. Not recognizing that Granger was alluding to blacks' bitterness about violence against blacks in the deep South in response to the Brown decision, Eisenhower

\footnotetext{
${ }^{54}$ Siciliano, Walking on Sand, 163-164; Branch, Parting the Waters, 235-236. Morrow's diary account in Black Man in the White House, 233-234, is surprisingly perfunctory, emphasizing that it was "pleasant" and that both sides "benefited." He adds little to it in Forty Years a Guinea Pig.
} 
expressed his "extreme dismay" that blacks felt bitterness after five and a half years of effort and accomplishment. Perhaps more action on the administration's part, the president said, would yield only more bitterness. Granger assured the president that the bitterness alluded to was directed at the segregationists, not at the administration. Eisenhower then relaxed and the conversation continued about twenty minutes beyond the scheduled half hour. At its close Eisenhower reaffirmed the Administration's support for stronger voting rights legislation. The black leaders were then invited to offer their comments to the press in the Fish Room of the White House. ${ }^{55}$

How tense things became in wake of Granger's "bitterness" comment is a matter of some dispute. Relying for some of his account on Roy Wilkins' memoir, Standing Fast, Taylor Branch depicted the meeting as uncomfortable. Morrow called it "pleasant." Siciliano in his memoirs took the same tack as Morrow, emphasizing both the intensity and the positive vibration that he felt listening to participants engage one another. The tone and texture of the meeting, clearly, was a matter of perspective. Not every participant took away the same sense of the meeting and what was achieved. Historian David Nichols has aptly emphasized the "perceptual gulf" between the president and his white aides on one side, and the civil rights leaders on the other. ${ }^{56}$ For example, while Morrow and Siciliano viewed the meeting as a fundamental success-in Siciliano's view, an "unqualified" success-the black leaders had a different take. Based on his experience listening to the president Granger told Urban League colleagues that Eisenhower was "not nearly as well informed on the day-to-day developments that were our concern as either of his two predecessors." King concurred, telling journalist Mike Wallace two days later that he doubted Eisenhower was

\footnotetext{
55 Siciliano, Walking on Sand, 164.

${ }^{56}$ Nichols, A Matter of Justice, 221. Wilkins' memoir, Standing Fast (New York: The Viking Press, 1982), 255-258, was acidic about the meeting. Both Siciliano and Morrow recalled a more positive contemporary response from Wilkins, a point supported by Wilkins' letter to the president June 25, 1958, as printed in Morrow, Forty Years a Guinea Pig, 177-178 and Wilkins to Robert Rivers of New York City, June 30, 1958, copy in Morrow Papers, Amistad Collection, Box 3.
} 
deeply committed to black civil rights. "I think he believes it would be a fine thing to have an integrated society, but I think he probably feels that the more you push it, the more tension it will create so you just wait 50 or 100 years and it will work itself out," King told Wallace ${ }^{57}$ In retrospect, King's analysis seems acute. Eisenhower always viewed himself as a moderate on race issues, fending off extreme civil rights activists on one side and thuggish white supremacists on the other as he sought what he viewed as a sensible middle way. ${ }^{58}$

Eisenhower's meeting with black leaders was undoubtedly helpful to all its participants in some measure. It was, as Fred Morrow later suggested, "historic." The ice had been broken and dialogue had ensued. By his presence the President expressed his interest in what the black leaders had to say, even if he was defensive about their frustration with the continuing stigma they faced in a society that favored white people over black. That said, the meeting did not usher in a new era of presidential interest and commitment to the cause of black civil rights. Eisenhower had treated it as a kind of unpleasant duty. The meeting receives no mention in his memoirs and there is little evidence that the president's attitude about black civil rights was affected by conversing with leading figures in the movement. In his memoirs Rocco Siciliano suggested that the meeting represented tangible evidence of the president's "personal concern" for civil rights. If so, that concern was largely obscure to the black leaders, even as they grasped the symbolic value of a dialogue with the President on his turf.

\footnotetext{
${ }^{57}$ On the meeting as an "unqualified" success, see Siciliano's memo to Eisenhower, quoted in Walking on Sand, 170. For a succinct account of the meeting, weighted to the perspectives of the black leaders, see Clayborne Carson's introduction to The Papers of Martin Luther King, Jr., IV, 28-29. A transcript of King's interview with Mike Wallace on June 25, 1958, is in this volume, pp. 431-441.

58 This notion permeates James C. Duram, A Moderate Among Extremists: Dwight D. Eisenhower and the School Desegregation Crisis (Chicago: Nelson Hall, 1981). It is evident also in Nichols, A Matter of Justice, passim. Nichols' work is more discerning in distinguishing Eisenhower's personal views on race from his policy decisions.
} 
The meeting may well have meant the most to Morrow and Siciliano, both of whom invested a great deal of time and emotional capital in making it happen. For the rest of his life, in numerous interviews with scholars and public historians, Morrow cited his role in making this meeting possible as his "finest hour" in the White House and one of the highlights of his life. It is apparent from Siciliano's memoirs that he felt the same way. ${ }^{59}$ Yet Clayborne Carson makes a reasonable point when he calls the aftermath of the meeting a distinct "letdown" for civil rights supporters. There would be no "clarion call" such as Morrow or the black leadership hoped might emanate from the White House, and there were no further meetings with these or other black leaders. ${ }^{60}$

The same week that Morrow joined his colleague Rocco Siciliano at that meeting, White House Chief of Staff Sherman Adams was grilled by House investigators about gifts he had been taking from a sleazy New England businessman, Bernard Goldfine. Adams insisted that he had never done anything to advance Goldfine's interests in return, but the trail of evidence of Adams' phone calls made to regulatory agencies at Goldfine's behest was damning enough on its face to spark calls for Adams' resignation. The crusty New Englander tried as best he could to ride out the storm, but the so-called Goldfine scandal took its toll on the Republican Party's popularity and by September, Adams was forced to resign. ${ }^{61}$

\footnotetext{
${ }^{59}$ For the "finest hour" quote see Morrow's response to a query from the Johnson Publishing Company of Washington, n.d. copy in Morrow Papers, Box 1, Amistad Collection, Tulane University Special Collections. ${ }^{60}$ Carson, introduction to The Papers of Martin Luther King, Jr., IV, 28. Eisenhower did meet occasionally with prominent African Americans for brief conversation and photo opportunities, as on August 22, 1958, when Morrow helped orchestrate an oval office visit for the leadership of the national black Elks organization, then convening in Washington. On this see Black Man in the White House, 243-244.

${ }^{61}$ The most detailed account of Adams' travail in 1958 is Michael J. Birkner, "Sherman Adams' Fall, and the Scandal Behind the Scandal," in Alison Dagnes and Mark Sachlaben, eds., Scandal! An Interdisciplinary Approach to the Consequences, Outcomes, and Significance of Political Scandals (New York: Bloomsbury, 2013), 127-153. See also Newton, Eisenhower, 281-286 and Ambrose, Eisenhower the President, 468-469, 480-482.
} 
Adams's resignation was a double blow to Morrow. It was Adams who had recruited Morrow to the Eisenhower campaign in 1952, given him steadily more meaningful assignments, and, when Eisenhower won the election, it was Adams who promised him a White House job. Once Adams finally delivered on this promise in 1955, Morrow knew he could count on Adams for support as he pressed the cause of minority rights. Speaking to a largely African American audience in Englewood, New Jersey, in October 1955, Morrow noted that aside from his own father, no two individuals had made a greater impact on him than Dwight Eisenhower and Sherman Adams. "None has ever taken my hand and planted my feet so firmly in the path of equal opportunity to serve my country and my race as a first class citizen," he observed. ${ }^{62}$ For Morrow, Adams's departure was a public tragedy and a personal loss. As he wrote in his White House memoir, "there was a camaraderie between us that is hard to define."63

There would be no such camaraderie with Adams's successor; this was the second blow. In appointing General Wilton Persons to replace Adams, Eisenhower was leaning on someone he had known and trusted since World War II and who had earned his respect for his smooth and effective work in Congressional liaison in the first five and half years of his administration. By all accounts Persons was a logical choice for the position. Although he lacked Adams's colorful style and decisive approach to decision making, he handled the job for the remainder of Eisenhower's presidency in a manner that satisfied his boss. ${ }^{64}$

\footnotetext{
${ }^{62}$ Morrow speech, October 27, 1955, copy in E. Frederic Morrow Papers, Box 1, Amistad Center, Tulane University Special Collections. For a similar expression, see Black Man in the White House, 253. In a phone interview on July 23, 2004, William B. Ewald, a White House speechwriter under Eisenhower, credited Adams with Morrow's appointments at Commerce and in the White House and called Adams Morrow's "benefactor."

${ }^{63}$ Black Man in the White House, 254. In a later entry in his revised White House diary Morrow observed that "people who recognize my bond with Sherman Adams now realize that I am more or less alone as far as having a strong friend at court is concerned." Ibid., 257. In the many oral histories he gave over the years, Morrow consistently cited Adams as his best friend in the White House.

${ }^{64}$ See, for example, Eisenhower's comments in Waging Peace: The White House Years, 1956-1961 (Garden City, New York: Doubleday \& Company, Inc., 1965), 318-319. For a contemporary assessment early into Persons' work
} 
Civil rights, however, was not merely on a low rung on Wilton Persons' agenda as Adams's successor; it was not on his agenda at all, as he made clear to Fred Morrow in the early months of his tenure. An Alabama native whose brother was a hard-core segregationist Democrat politician; Persons was uninterested in advancing minority rights. Only weeks into the job, the new Chief of Staff made a racist comment in Morrow's presence. When Morrow, not having clearly heard Persons' quip, asked him to repeat what he said, Persons did so, looking Morrow squarely in the face. ${ }^{65}$ Subsequently Morrow felt increasingly isolated in the White House. Adams was gone and by 1959 so was Rocco Siciliano. From a social perspective Morrow was also disheartened. Where Rachel Adams had made a point of reaching out to Catherine Morrow for the regular White House wives' gatherings, no invitations were extended subsequently. Morrow took regretful note. ${ }^{66}$

Beyond his attendance at regular staff meetings, Morrow saw little of Persons thereafter. Finally, in late winter 1959 he made an appointment to see his nominal boss, who he felt had "no idea" of his job responsibilities. The meeting was cordial. Morrow briefed Persons on his work, and Persons assured Morrow that his door would "always be open" to Morrow. However, he told Morrow that he wanted Morrow to discuss all civil rights and racial matters with White House Counsel Gerald Morgan rather than with him. ${ }^{67}$

as Assistant to the President, Felix Belair, Jr., "Persons Has His Own Way of Doing Adams' Job," New York Times, October 19, 1958.

${ }^{65}$ Morrow, Black Man in the White House, 258.

${ }^{66}$ Ibid., 277. It is evident from this work and others that Sherman Adams's spouse Rachel had periodically eased the way for Catherine Morrow's participation in White House wives' activities. But by September 1958 Rachel Adams was no longer in a position to play that role. On this, Ibid., 214-215.

${ }^{67}$ Black Man in the White House, 277. In his oral history with Ed Edwin for the Eisenhower project in 1968 he offers a variant version of this encounter, dating it at 1957- before Adams left office. In his 1980 memoir, Forty Years a Guinea Pig, 192-193, Morrow dates his encounter with Persons to "days" after Persons took over from Adams in fall 1959. In this version (as in the oral history) Persons tells him to "go to anybody else" about matters relating to civil rights. Later in this book, 199-200, Morrow relates how in 1960 Persons called him into his office to encourage him to stay on the job rather than join the Nixon Presidential Campaign on a full-time basis-an opportunity that Morrow was at that point not even aware was in the offing for him. 
Morrow accepted this new circumstance, mollified in some measure by his awareness that Morgan was among the more sympathetic members of an administration wary of pressing too forcefully in the realm of civil rights. Morrow had plenty of work to do explaining Eisenhower Administration initiatives to interest groups and Republican organizations, and in his ongoing back and forth with leaders of the NAACP, the Urban League and other important black lobby groups. Much of this work was vexing. Morrow was trying to raise the Administration's consciousness on racial matters and encourage the president to expand his personal commitment to advancing minority rights. At the same time Morrow was attempting to temper or parry demands from black activists who wanted the administration to express solidarity with various groups campaigning for emphatic action to assure racial equality. One ongoing headache related to the efforts of A. Philip Randolph and other black leaders on behalf of a march on Washington by young people, in order to highlight the "undemocratic resistance to integrated schools" and to "arouse the conscience of America." 68 The idea behind the plan was to march a thousand black and white students down Pennsylvania Avenue and present a petition to Congress urging more aggressive action on school integration. The spearhead of this initiative, Randolph, sought an audience with the president for a select group of the student marchers as a means of highlighting the issue of school integration. "The children's march in Washington," he explained to a reporter, "was conceived as a method of giving dramatization to the whole civil rights struggle." 69

\footnotetext{
${ }^{68}$ Morrow, Black Man in the White House, 263; Paula F. Pfeffer, A. Philip Randolph, Pioneer of the Civil Rights Movement, 180. On Eisenhower's reluctance to get ahead of mainstream racial opinion in his civil rights policy initiatives, Duram, A Moderate Among Extremists, passim, and Riley, The Presidency and the Politics of Racial Inequality, chapter 6. Morrow saw Eisenhower as preternaturally conservative on the issue of race and surrounded by friends who were unsympathetic to minorities. Oral History with Ed Edwin, 1968, Eisenhower Oral History Project.

${ }^{69}$ Pfeffer, A. Philip Randolph, 180.
} 
The so-called "young people's march" was a delicate matter for the White House, which preferred, if it could, to let the courts and the goodwill of a majority of Americans to resolve, over time, the matter of school integration. Morrow was in the cross hairs, as the man who had helped arrange the leadership meeting with Eisenhower in June. This time he would play a different role. After investigating the matter thoroughly, including reviewing confidential reports on the supposed communist leanings of some of the leading marchers, Morrow wrote memos arguing against any special cooperation with the enterprise. In a private meeting in his office with baseball great Jackie Robinson, he told Robinson that he should remain aloof from the march because he could be tainted by his association with known communists. In any case "I told him that I felt that the march would prove nothing." Besides, the president was well-informed about the issue of school integration. And why should opponents of integration be given an opportunity to lump all protestors under the banner of troublemakers? Although the march took place as planned, there was no meeting with the president. Subsequently it was Morrow's responsibility to reply to the scores of letters from "irate people across the country, damning the president" because he did not receive a delegation of the marchers. ${ }^{70}$

Within months, the issue of a march on Washington again occupied much of Morrow's time and emotional energy. Randolph wrote the president on February 17, 1959, explaining that another march would be organized for April 18. He noted that in the autumn "certain misunderstandings" resulted in disappointment at not having the opportunity to communicate directly with the president. He added that the young people were "deeply grieved" at not being

\footnotetext{
${ }^{70}$ Morrow, Black Man in the White House, 263-264. On the meeting with Robinson see Morrow Oral History with Ed Edwin, 1968 and Morrow interview, 1968, with the Civil Rights Documentation Project, Amistad Collection, Tulane University. In his diary Morrow noted that Attorney General William Rogers visited his office to explain why he thought any involvement with the march was a poor idea; whether Morrow was fully convinced or felt from a political point of view it made sense to follow Rogers' line is not clear.
} 
able to see Eisenhower in 1958 "in light of the positive steps you and your administration have taken." He urged Eisenhower to see the group this time. ${ }^{71}$

The issue was bruited among White House staffers, among them Press Secretary James Hagerty, Appointments Secretary Thomas Stephens, special advisor Fred Seaton, and Morrow. The consensus held that Eisenhower or a designated deputy could meet a small delegation of the student marchers, but that Randolph's follow-up request that popular singer and civil rights activist Harry Belafonte join the delegation was not acceptable. Seaton suggested that meeting Belafonte would do no good for anyone save Belafonte's ability to "sell more records."72 Morrow viewed the inclusion of Belafonte in the delegation as a "publicity seeking stunt" and shared this view with others. In a memo for Hagerty, Morrow told of calling Randolph and speaking to him in "very sharp tones" to the effect that "no one should try to pressure the President of the United States into doing anything." The White House, he concluded, should meet with a small delegation of young people to accept their petition, period. ${ }^{73}$ The 1959 march took place as scheduled in April. Some 22,000 people, most of them youths, marched along the Mall to the Washington Monument, singing, chanting and waving signs and pennants with civil rights slogans. When the student delegation reached the White House, the president was playing golf in Augusta. White House Counsel Gerald Morgan met them, accepted their petition seeking presidential support for speedy integration of the nation's schools, and conveyed the president's commitment to end discrimination in the United States. While Morrow encouraged further follow-up and Eisenhower

\footnotetext{
${ }^{71}$ Randolph to Eisenhower, February 17, 1959, OF 142-A-5-A, Box 732, Eisenhower Presidential Library.

72 Seaton to Stephens, March 23, 1959; Morrow "Memo for the Record," March 25, 1959; both OF 142-A-5-A, Box 732.

${ }^{73}$ Morrow to Hagerty, April 10, 1959, OF, 142-A-5-A, Box 732, DDEL.
} 
sent a note to the delegation promising that his Civil Rights Commission would take its recommendations into account, that was the extent of his direct engagement with the issue. ${ }^{74}$

Throughout 1959 Morrow continued to put in long hours at work, fending off critics who charged that Eisenhower was not moving fast enough for the cause, even as his heart told him the critics were right. According to historian Michael Mayer, he felt awkward "standing on platforms all over the country, trying to defend" the administration's civil rights record. Devoting himself increasingly to speechmaking, Morrow's sense of frustration kept building. ${ }^{75}$ In April 1959 he delivered speeches in Detroit and Washington, respectively, which pointedly criticized his party's failure to engage with black voters or invite black leaders into their councils. After one Republican official asked him, "What do we have to do to make friends with Black voters and get their support?" Morrow felt a surge of annoyance. While he did not respond sharply to the questioner, in his Detroit speech he "took the gloves off," as he later put it, "and let them have it." Blacks simply were not integrated in Republican Party affairs in Michigan, while Democratic leaders in the state were going "out of their way to make friends of Black voters."76 The Detroit speech raised eyebrows but generated relatively little response. A similar speech that Morrow delivered to a Republican Woman's convention in Washington, DC, the same month received more attention, both positive and negative. Members of the Republican National Committee felt insulted by Morrow's remarks. Morrow was gratified that the black community responded more favorably to his talk, judging by the many phone calls, telegrams, and letters commenting on it. But there

\footnotetext{
${ }^{74}$ On the marches and the Administration's responses see Pfeffer, Randolph, 180-185. Congruent with historian Robert Burk's critical account of Eisenhower and civil rights, Pfeffer portrays the president as fundamentally unsympathetic with black aspirations and disengaged from the cause of advancing black rights. See also Milton S. Katz, "E. Frederick [Frederic] Morrow and Civil Rights in the Eisenhower Administration," Phylon 42 (June 1981): 141. On Morgan meeting the marchers, Garrow, Bearing the Cross, 117.

${ }^{75}$ Mayer, "E. Frederic Morrow," in Mayer, ed., Presidential Profiles: The Eisenhower Years (New York: Facts on File, 2010), 533. On the increase in Morrow's time devoted to speechmaking, Black Man in the White House, 204. ${ }^{76}$ Morrow, Forty Years a Guinea Pig, 193-194.
} 
was a cost to following what his "conscience" dictated. In the White House Morrow felt increasingly isolated. It did not help his morale when African American appointees to the administration left their posts for other opportunities and they were not replaced. ${ }^{77}$

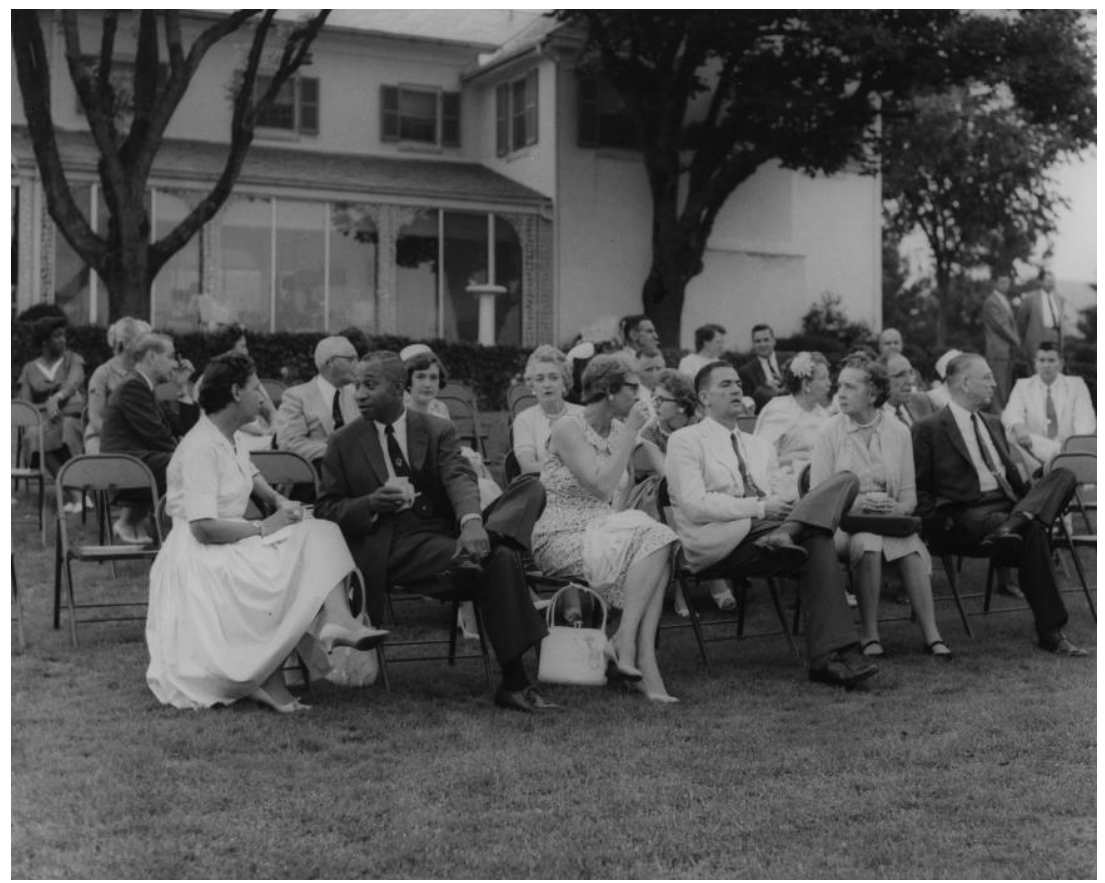

This photo of Morrow and his wife Catherine was taken when they attended a 1959 picnic for White House staff and their spouses at President Eisenhower's Gettysburg farm. Photo courtesy of the Eisenhower National Historical Site, Gettysburg, PA.
In his published diary

Morrow told of social affairs where members of the staff avoided him and his wife. ${ }^{78}$ Periodically, Morrow would experience reminders of blacks' second-class status in the nation's capital, whether it related to finding a place to eat or to live. Morrow never found a comfort zone in Washington beyond his apartment. There's no evidence he made much effort to engage what was a vibrant black community in the city, before or after his marriage in 1957. In a handwritten draft addendum to Forty Years a Guinea Pig, Morrow recalled his first two "lonely, nerve-wracking years in Washington devoid of outside social intercourse and any meaningful relationships." He avoided virtually all social functions and became, he said, "a voluntary recluse." ${ }^{\text {79 }}$ Life improved during his tenure in the White House and especially after his marriage in 1957, but Morrow continued to

\footnotetext{
${ }^{77}$ Ibid, 194-195, 212; also, “E. Frederic Morrow,” 532-533.

${ }^{78}$ Morrow, Forty Years a Guinea Pig, 196-197.

${ }^{79}$ Typescript draft with handwritten addendum in Morrow Papers, Amistad Collection, Tulane University Special Collections, Box 1.
} 
refrain from reaching out to potentially sympathetic peers in the White House, on the basis of what he once admitted was a lifelong character trait he could not break.

Even before Sherman Adams left Washington in September 1958 Morrow had been thinking about leaving the White House. He watched other staff members accept lucrative positions in the legal world or elsewhere in the private sector. Always financially living on the edge, given his ongoing financial support for his widowed mother and stake in the new Morrow family home in Teaneck, New Jersey, Morrow thought often about ways he might improve his financial lot. In 1957 he wrote to Clarence Francis about the possibility of moving on to a post with the Ford Foundation. Months later he made contact with a representative from U.S. Steel, to discuss possibilities, but nothing came of either contact. ${ }^{80}$ In wake of these disappointments, Morrow persuaded himself that he would be abandoning his duty to his country, Black Americans, and to his president if he left the White House prematurely. As he put it years later in a speech at a Black History seminar in his native Hackensack, "In the areas that vitally affected my race" during the Eisenhower years, "much was left undone... But I stayed the course, because no soldier should desert his post because he may be overcome." 81

Morrow's views of President Eisenhower were complicated. He always said he admired the nation's $34^{\text {th }}$ chief executive for his personal kindness and commitment to equal treatment for all Americans. It was not difficult for Morrow to praise the Administration's accomplishments in the realm of minority rights, since there was a good deal that had been accomplished in the realm of appointments of African Americans to meaningful positions in the federal bureaucracy,

\footnotetext{
${ }^{80}$ On looking for a new position in the private sector, see Black Man in the White House, 209-210, and Forty Years a Guinea Pig, 177-179. In the latter he details recounts in detail a distinctly uncomfortable conversation with a racist attorney who had contacts with numerous leading corporations. For a discussion with a representative of U.S. Steel, see John A. Stephens to Morrow, May 8, 1958, Morrow Papers, Amistad Collection, Box 3.

${ }^{81}$ Speech text in Morrow Papers, Box 1, Amistad Collection, Tulane University.
} 
Eisenhower's enlightened judicial appointments, his civil rights legislation, and the president's effective integration of public facilities in Washington DC and at military installations. The president signed the U.S. Commission on Civil Rights into law in 1957. That same year Eisenhower had stood up for the Supreme Court's Brown decision by sending federal troops to assure the integration of Central High School in Little Rock, and in the course of enforcing the law made it clear that further efforts to ignore or challenge court orders with mob actions would not be tolerated. In Fred Morrow Eisenhower had appointed an African American to a place on his executive staff, the first such appointment in American history. All of this was evidence Morrow could draw on in spreading the word nationwide that the Republican Party and its president were stronger on civil rights than the hydra-headed Democrats.

Yet for all this Morrow was consistently conflicted during his White House service. For every success in moving a few steps forward to the promised land of equality, Morrow felt the president had missed opportunities. In the wake of the Emmett Till murder, Morrow had urged the president to convene a conference of white and black leaders to discuss the status of black Americans. No such meeting ensued. Morrow's requests for meetings between the president and black leaders reached a kind of fruition, as we have seen, in June, 1958, but there was virtually no follow-up. The President had difficulty, when addressing black groups, avoiding offensive phrases like referring to his audience as "you people." His calls for patience and tolerance in the black community in their stride toward freedom did not go down well at a time when White Citizens' Councils and other arms of the Ku Klux Klan were terrorizing blacks who challenged white supremacy. Fred Morrow knew from hurtful experience what it was like to be condescended to, excluded, and abused. During his time as a field organizer for the NAACP, he had experienced the raw fear of being chased by members of the KKK. He wanted the president-his president-to 
deliver more ringing calls for equality and to take more dramatic measures through executive orders. But these actions and orders did not occur. It added up, in Morrow's view, to a "lukewarm" approach to black civil rights. ${ }^{82}$ Eisenhower's failure to "seize leadership in this vital moment," Morrow recalled later, was "sheer trauma for me." 83

At the same time Morrow knew he had an obligation to defend the man who had made him an example of black progress in America. It was not an easy position, and someone as sensitive as Morrow felt every cut even more profoundly than another person in his shoes might have done. Because of his loyalty to his boss-and desire to keep his job-he consistently defended Eisenhower's stewardship, citing points of light rather than the battles not fought, noting in particular the effective desegregation of the nation's capital during the Eisenhower presidency. In later years Morrow referred to the $34^{\text {th }}$ president in terms of his laudable human qualities. As a human being he was "A+ and Summa Cum Laude," Morrow told a black history seminar in New Jersey in later years. But he never backed off his belief that Eisenhower had missed too many chances to do more for a righteous cause. ${ }^{84}$

As the clock ticked down on the Eisenhower Administration, Morrow had to consider his self-interest. He did not intend to resign, but he proved willing to take a leave of absence to work for Richard Nixon's presidential campaign. Morrow watched Nixon in action in the White House and admired his advocacy of black civil rights. Having travelled with Nixon on an exhilarating

\footnotetext{
${ }^{82}$ Morrow, Black Man in the White House, 299. On Eisenhower and "you people," see Morrow Oral History conducted by Thomas Soapes, 1977, Eisenhower Library Oral History Project.

${ }^{83}$ Morrow's Lambright Lecture, Cleveland, Ohio, April 8, 1970, in Morrow Papers, Box 1, Amistad Collection. In Black Man in the White House, 299, he referred to being "heartsick" at the president's failure of leadership. Morrow's comment in his book no doubt contributed to the icy reception he received at a reunion of Eisenhower and his staff at the Hershey Hotel in 1964.

${ }^{84}$ Transcript of Morrow speech to a Black history seminar, Hackensack, NJ, n.d. Box 1, Amistad Collection, Tulane University. In 1973 Morrow described Eisenhower as a "gentle and noble man" who was unable to combat racial discrimination "intellectually or emotionally." See also Dick Burnon, "Black Author's Book Recalls Turbulent Years in Hackensack," [Bergen County] Town News, Dec. 19, 1973.
} 
trip to Africa in 1957, Morrow felt, at first, confident that Nixon would be a worthy successor to Dwight Eisenhower, especially so on the issues that mattered most to Morrow. He signed on enthusiastically to Nixon's campaign, viewing it as an opportunity to woo and win black votes on the basis of the Eisenhower administration's record and Nixon's commitment to advancing minority rights. "For the candidate who understood and listened [to black America], this was the easiest campaign of all," Morrow thought. ${ }^{85}$

It did not turn out that way. Once he had worked out pay and other arrangements that he insisted on before agreeing to advise the Nixon campaign full-time, Morrow soon found himself marginalized and largely ignored. While Morrow relished an opportunity to offer his views on Nixon's decision about a Vice Presidential nominee-Morrow favored Henry Cabot Lodge, the ultimate choice-there was little else that proved satisfying to him in the race against John F. Kennedy. Small matters and larger ones frustrated him. He was never given a secretary to help with his mail. He had no budget for assistants, campaign literature, or anything else. He had to lobby to get even a small speaking role at the Republican National Convention and once near the convention, found he had not been given the necessary pass to enter the hall. Where he had ridden close to the candidate in motorcades in the 1952 campaign, in 1960 Morrow was invariably at the back or forgotten entirely. He "begged" Nixon's campaign aides to have the candidate contact Martin Luther King in wake of his arrest on trumped up charges in Georgia on October 19, 1960. He drafted statements, too, but they, like his advice, were ignored. ${ }^{86}$ It was as though the Nixon campaign had decided that black votes did not matter. They did, contributing materially to John F. Kennedy's razor thin triumph in the 1960 election.

\footnotetext{
${ }^{85}$ Morrow, Black Man in the White House, 292.

${ }^{86}$ Ibid., 292-296.
} 
Assessing Fred Morrow's role in advancing Eisenhower Era civil rights is no simple matter. One cannot write him off as a token in an administration indifferent to black civil rights, since we now know in much more concrete detail the ways in which Dwight Eisenhower advanced that cause. Even a cursory examination of the documentation of Morrow's work in the White House will demonstrate that he took his role seriously as a voice for those who had few advocates in the highest councils of the government. Morrow's advocacy of a conference between the president and black leaders advanced that enterprise once Max Rabb left the White House and Sherman Adams had more say about the matter. Morrow's salesmanship for the Administration brought attention, particularly in the black community, to the administration's efforts on behalf of racial equality, and along with the unsung organizational work of Val Washington (administrative liaison to Congress on minority affairs), helped sustain networks of black Republicans and build their morale. ${ }^{87}$ This work also set the stage for Richard Nixon's campaign in 1960 . That Nixon did not exploit and build on this work, doubtless as he sought to win votes in the South, did not mean that Morrow's labors lacked value.

From a long view Morrow's experience in the White House may have been less important for what he did than what he represented. He was a pioneer, blazing a new trail. He was always caught between militants in the black community who believed that the times were changing too slowly, and political conservatives satisfied with the racial status quo. The 1950s was not an era when dramatic statements were likely to upend long-standing racial prejudices. It was not a time when substantial integration of African Americans into suburban communities and the higher echelons of the professions was possible. But it was an era of beginnings in a much-delayed assault

\footnotetext{
${ }^{87}$ On Washington, who also sought to build connections to the black community through his work for the Republican National Committee, see Michael Mayer, "Valores James Washington," in Mayer, ed., Presidential Profiles: The Eisenhower Years (New York: Facts on File, 2010), 808-809.
} 
on segregation, racial double standards, and the pathologies of white supremacy. Fred Morrow labored with all his ability and all his heart to advance the cause. He deserves to be better known and appreciated for the halting steps towards equality that would, within another decade, become more emphatic and the results more profound.

Michael J. Birkner is Professor of History at Gettysburg College, where he has taught since 1989. He is the author or editor of several books on New Jersey History, including Samuel L. Southard: Jeffersonian Whig (1984); A Country Place No More: The Transformation of Bergenfield, New Jersey (1994); McCormick of Rutgers: Scholar, Teacher, Public Historian (2001); and The Governors of New Jersey: Biographical Essays (2013). He is also a contributor to Maxine Lurie and Richard Veit, eds., New Jersey: A History of the Garden State (2012).

The author wishes to acknowledge the Gettysburg College Faculty Development Fund for financial support in researching this article. Thanks also to the following readers for discerning comments on an earlier draft: Stephen Benedict and Roemer McPhee, both of whom served in the Eisenhower White House; C. Mike Pride, and Daun Van Ee. Carol Hegeman, retired Supervisory Historian at the Eisenhower National Historical Site, provided a helpful assist securing the photograph of the Morrows in the files of the Eisenhower Farm office. 